\title{
Chapter 7 The Role of Private International Law: UNIDROIT and the Geneva Conventions on Arbitration
}

\author{
Herbert Kronke"
}

\section{Introduction: Terminology and the Historical Context}

As is obvious from the title, the term 'private international law' is not intended to be synonymous with 'conflict of laws' but, in the North American tradition, as the entirety of international law not relating to state-tostate relationships. It is clear that World War I and its aftermath mark key moments in the development of organized and institutionalized research in the fields of comparative law, conflict of laws, the law of dispute resolution and transnational commercial law. To a varying extent they were driven by economic expansion and rivalry, the war and, following its catastrophic outcome, the quest for peace. For many post-WWI lawyers, one of the main functions of harmonized law was to build and maintain this peace by fostering an orderly and universally beneficial commercial exchange. As I used to tell visitors, this historic peace-making and peacebuilding function is still an integral part of UNIDROIT's present-day mission.

Within this historical development, the years 1916 and 1926 are particularly significant. The former sees the founding of the first two academic institutions with staff and funding devoted exclusively to private international law, that is, the institutes affiliated with the universities in Heidelberg and Munich. In 1926, at the national level, the Kaiser Wilhelm Institute in Berlin (now Max Planck Institute for Comparative Law and Private International Law in Hamburg) and, at the international level, the International Institute for the Unification of Private Law (UNIDROIT) in Rome see the light of the day. The-explicit or implicit-objectives of these institutions differed widely. In the deed of trust of the Heidelberg institute, its founder, the elder of the Berlin merchants Carl Leopold Netter, expressed the desire 'to testify that, even in times of war, the work for peace is not forgotten. Consequently, the aim of that institute was to fund research and

* Professor emeritus, Heidelberg University School of Law. Arbitrator, Iran-United States Claims Tribunal. Former Secretary-General of UNIDROIT. 
the study of non-German law, primarily private law, commercial law, civil procedure as well as the relationship between law and the economy. The Kaiser Wilhelm Institute, on the other hand, was intended to build up the necessary expertise for dealing with the fall-out of the war, in particular non-performed commercial contracts and Germany's foreign debt.

\section{UNIDROIT}

\subsection{The Institutional Framework}

The International Institute for the Unification of Private Law/Institut International pour l'Unification du Droit Privé (UNIDROIT) was set up in 1926 as an auxiliary organ of the League of Nations pursuant to Article 24 of the Covenant. ${ }^{1}$ Remarkably, if looked at with knowledge of how intergovernmental organizations are working today, it took the League's Council not more than twenty minutes to complete its creation. Then, more than now, it was really all about the individuals involved. One of these figures was Antonio Scialoja, distinguished professor of Roman law at the University of Rome, Senator of the Kingdom and Deputy Secretary-General of the League. Scialoja was convinced that after a century of nationalization of private law the time was ripe for returning to a common law of 'civilized' nations-at least in Europe. He had identified ways and means to work towards achieving this, and he had even won over the king. In 1924, the Council of the League had accepted ${ }^{2}$ the offer of the Italian Government to establish and maintain an institute for the purpose of 'harmonising and coordinating the rules of Private Law of the different states or groups of states, with a view to promoting gradually the adoption of a uniform system of Private Law by the various states. ${ }^{3}$ At a meeting of the Council on 15 March 1926, Scialoja 'read his report (Annex 849) and submitted the following draft resolution. "The Council adopts the present report and the draft Statutes annexed thereto" (Annex 849a). And, following a brief exchange relating to the correct translation of the Italian term 'argomento' in-

1 For a detailed account, see Lena Peters, 'International Institute for the Unification of Private Law (UNIDROIT)' in International Encyclopedia of Laws, International Organisations, Suppl 55 (Kluwer 2014).

2 LoN, Council, 30th session, 19th meeting (3 October 1924) 5 LNOJ 1369, 1375.

3 Letter dated 3 October 1924, League of Nations document C.262.M.101. 
to French ('matière'), the report of the meeting concludes, 'The resolution proposed by M. Scialoja was adopted. ${ }^{4}$

On 30 May 1928, in the presence of the King of Italy, the members of the Diplomatic Corps, other dignitaries, and the members of the Governing Council of UNIDROIT, the Prime Minister of Italy, Benito Mussolini - a journalist turned politician-opened the session with brief remarks on the intended role of the country and the now established institute to conduct research on the relationship between law and commercial activity with the intention of promoting the latter by harmonising the former. The representative of the President of the Council of the League of Nations replied:

To unify the rules of private law means working toward the creation of a universal law ... [I]t means knocking down one of the most formidable barriers separating individuals of different origins; it means, in short, ensuring the peaceful and productive development of peoples... In Savigny's time, the focus lay purely on scientific work. Today's enterprise is essentially a practical one. However, it is also more difficult and more useful to humanity. The League of Nations' working method and its ultimate aim in different fields of action is to overcome existing divergences through superior unity. This is also the working method and the ultimate aim of the new institute. ${ }^{5}$

Initially, the members of the Governing Council, the body in charge of shaping the Organization's policies and, in particular, its work programme, were appointed by the Council of the League of Nations. Among the 14 members appointed for the period 1928-1933, there were three Judges at the Permanent Court of International Justice (one of them, Sir Cecil J.B. Hurst, had been a British negotiator at the Versailles conference), one international-law adviser and, previously as well as again later, Foreign Minister and Prime Minister of Sweden (Östen Undén) and Mussolini's Minister

4 LoN, Council, 38th session, 3rd meeting (15 March 1926) 7 LNOJ 504, 506.

5 French original: 'Unifier les règlements du droit privé, cela signifie travailler à la création d'une loi universelle, ... cela signifie abattre une des barrières les plus formidables qui séparent les individus d'origine diverse; cela signfie, en un mot, assurer le développement tranquille et productif de la vie des peuples... Il s'agissait, au temps de Savigny, d'accomplir un travail purement scientifique. Il s'agit aujourd'bui d'une ouvre essentiellement pratique, et, pourtant, plus difficile et plus utile à l'humanité. Réunir dans une unité supérieure les divergences qui se présentent: voilà la méthode de travail et le but suprême de la Société des Nations dans les différents champs d'action, voilà la méthode de travail et le but du nouvel institut.' 
of Justice (Alfredo Rocco). These names reflect, on the one hand, the political weight member states accorded to this particular initiative of the League and, on the other hand, the still widely held view that private international law (including comparative law) was somehow a function of public international law. Of greater importance for the work programme was the presence on the Governing Council of two of the most distinguished private-law scholars of the time: Henri Capitant (France) and, even more so, Ernst Rabel (Germany), whose seminal comparative studies of the law of sales ${ }^{6}$ was already far advanced and who proved to be the decisive voice when it came to defining the first triennial work programme.

\subsection{The Work Programme, and the Individuals}

From the beginning, there was no shortage of ideas, projects, and demands as regards the work the Organization should take up: intellectual property, negotiable instruments and arbitration, to name but a few.

Arbitration is particularly associated with the name René David, one of the exceedingly rare examples of a universally known jurist. David had become a tenured professor in 1929 at the age of 23. One year later, he took office as one of UNIDROIT's two Deputy Secretaries-General, together with Hans Gerhard Ficker, a scholarly minded head of department in the German Ministry of Justice. David's interests were not limited to comparative law and approaches to the harmonization of law generally, but also included arbitration ${ }^{7}$. UNIDROIT as such, however, was never involved in the development of any instrument in this field, such as the Geneva Conventions. ${ }^{8}$

Ernst Rabel, who was since 1926 director of the Kaiser Wilhelm Institute $^{9}$ and also served as an ad hoc judge at the Permanent Court of International Justice and the German-Italian Mixed Arbitral Tribunal as well as the Permanent German-Italian and German-Norwegian Arbitral Commissions, had a clearer notion than others as to the limits of resources member states would be willing to make available and the need to focus

6 Eventually published as Ernst Rabel, Das Recht des Warenkaufs (vol 1, de Gruyter 1936/vol 2, de Gruyter 1958).

7 René David, Les grands systèmes de droit contemporains (1st edn, Dalloz 1964); id, 'The Unification of Private Law' in International Encyclopedia of Comparative Law, vol 2 (JCB Mohr 1971) ch 5.

8 See below, 3 .

9 See above, 1 . 
the Organization's work in a realistic direction. The Governing Council followed his advice, and UNIDROIT provided the institutional framework for the harmonization of the law of the international sale of goods.

Interrupted by Rabel's forced emigration to the United States in 1939 and World War II, the work was taken up again after the war and, in 1964, lead to the adoption of the two Hague Conventions. ${ }^{10}$ Both the Conventions and the preparatory work were, in turn, to serve as the basis for the 1980 United Nations Convention on the International Sale of Goods (CISG). Only in the post-World War II period, released from the shackles of political considerations, did the Governing Council effectively live up to its reputation as a 'republic of scholars'. Not only the scholars in the true sense, who, according to certain member states' traditions, were put forward for election by their respective governments, but also high-ranking civil servants in ministries of justice, trade or foreign ministries who served - in some cases - for decades conducted Governing Council business as though they were under no instructions, but only with regard for the substance, such as the economic rationale, the inherent legal merit and the feasibility of a project. Indeed, under the UNIDROIT Statute-ie from 1940 onward-the members of the Council have been elected by the Organization's own General Assembly, which is composed by the member states' governments. But, once elected, they serve in their personal capacity as experts. Without a shadow of a doubt, it is this intellectual freedom which shaped UNIDROIT as a uniquely innovative and productive private-law formulating agency. ${ }^{11}$

\subsection{7: Not the End, but a Transition into the Unknown}

In March 1933, immediately after the Nazis had come to power, Germany gave notice of its withdrawal from the League of Nations, eventually becoming effective in 1935. Italy, the host state and principal funder of the Organization, followed in 1937. This, however, did not entail the demise of the Institute. Diplomatically shrewd, and skilled, the Italian Government

10 Convention relating to a Uniform Law on the Formation of Contracts for the International Sale of Goods (done 1 July 1964, entered into force 23 August 1972) 834 UNTS 169 (ULF). Convention relating to a Uniform Law on the International Sale of Goods (done 1 July 1964, entered into force 18 August 1972) 834 UNTS 107 (ULIS).

11 For details, see Herbert Kronke, 'UNIDROIT' in Encyclopedia of Private International Law, vol 2 (Edward Elgar 2017). 
circulated a draft Statute in 1939 for a-now independent-international Organization, and by 1942 practically all countries previously involved had adhered to the new treaty. As a matter of fact, however, the work was put on hold and did not recommence until well after the war had ended.

\section{The Geneva Arbitration Conventions}

\subsection{Political Background}

It is a highly plausible hypothesis that the rationale for negotiating the two instruments relating to dispute settlement was the desire to facilitate trade by providing legal certainty regarding the specific dispute-resolution mechanism typical for certain areas of trade and types of transactions, such as distance sales and maritime transport of the goods sold. The equation, quite in line with the conference's framework theme, would have been 'peace through trade. Indeed, there are traces in reports on the meetings suggesting that participants would have preferred to see the work on arbitration move faster. Moreover, and even if not explicitly reflected in the documents, recourse to and reliance on arbitration necessarily implied the assumption of a reduced emphasis on sovereignty as the basis of authority to resolve disputes.

Incidentally, notwithstanding the appetite for work on the law of arbitration shown by many during UNIDROIT's early years, the Organization was, as is obvious from the dates of their adoption, not involved in the preparation of the Geneva instruments. They were principally creatures of the International Chamber of Commerce.

The Geneva Protocol was adopted and signed by 25 states and eventually entered into force for 34 contracting states.

\subsection{The 1923 Protocol on Arbitration Clauses}

The principal purpose of this treaty was to overcome an arbitration-adverse peculiarity of certain legal systems, notably the French legal system. These systems refused to recognise simple arbitration clauses, eg those included in a sales contract or a charter party. Instead, they required a fully fledged 
'arbitration agreement' relating to a dispute that had already arisen. ${ }^{12}$ That agreement had to identify the subject matter of the dispute and even the arbitrators who were to serve on the tribunal. Given that, at the time when a contract is entered into, merchants were generally unwilling to even contemplate a future dispute and the details regarding its solution, this requirement obviously posed a significant problem for international commercial transactions.

The Protocol on Arbitration Clauses, signed on 24 September 1923 apparently remedied this unsatisfactory situation. Article 1(1) provides that the contracting states recognise the

validity of an agreement whether relating to existing or future differences between parties subject respectively to the jurisdiction of different Contracting States by which the parties to a contract agree to submit to arbitration all or any differences that may arise in connection with such contract...

The seemingly straightforward language turned out to be the first stumbling block, as 'subject ... to the jurisdiction of different Contracting States' was construed in a widely diverging manner in various contracting states. Both political factors-eg, in relation to colonies and mandatesand legal considerations in a strictly technical sense-eg, questions about the circumstances in which a person is subject to the jurisdiction of a state - contributed to these disharmonies. In addition, Article 1(2) provided for a reservation each contracting state could make to limit that obligation 'to contracts which are considered as commercial under its national law. Given the different mechanisms adopted in legal systems for distinguishing 'commercial' and 'civil' contracts (eg 'objective' v 'subjective' characterization) and, moreover, the absence of any meaningful distinction in some major legal systems, this was a significant carve-out that would eventually undermine the potential effect the Protocol was going to have. Indeed, half of the initially 25 contracting states did avail themselves of the right to make that reservation.

12 Peter Schlosser, Das Recht der internationalen Privaten Schiedsgerichtsbarkeit, vol 1 (1st edn JCB Mohr 1975). 


\subsection{The 1927 Convention on the Execution of Foreign Arbitral Awards}

This treaty built on the 1923 Protocol, Articles 6 and 7. It applied only to awards made after the coming-into-force of the Protocol and was open to signature only of signatories of the Protocol. Its principal purpose was to provide for a solution of a fundamental shortcoming reflected in Article 3 of the Protocol. Pursuant to that provision, contracting states had undertaken to ensure that only arbitral awards made in their respective territories would be executed by their authorities and in accordance with the provisions of their respective national laws. Article 1 of the Convention provides that in the territories of a contracting party to which the Convention applies, an award made in pursuance of an arbitration agreement covered by the 1923 Protocol shall be recognized and enforced in accordance with the rules of procedure of the territory where the award is granted, provided the award has been made in the territory of a state party to the Convention and between persons who are subject to the jurisdiction of one of the contracting states. In other words, while awards were now, in principle, capable of being granted in jurisdictions other than the one where they were made, other obstacles limited the creation of an effective 'space of free movement' for arbitral awards. First, two major restraints, or uncertainties, flowed from the 1923 Protocol, ie, the parties to the arbitration agreement were subject to the jurisdiction of one of the contracting states, and, in many instances, the relevant state characterized the contract as commercial. Second, the rules of procedure of the enforcement state had been complied with.

Conversely, the system of grounds for denying recognition and enforcement, as laid out in Articles 1, 2 and 3 of the Convention may seem relatively modern, at least at first sight. In addition to bringing the award within the (limited) scope, as outlined above, according to Article 1, five requirements must be met to obtain recognition or enforcement: (a) the award was made pursuant to a valid arbitration agreement; (b) the subjectmatter was capable of settlement by arbitration under the law of the country in which the award is sought to be relied upon; (c) the award was made by the tribunal provided for in the submission agreement and in conformity with the law governing the procedure; (d) the award has become final in the country in which it has been made; (e) recognition or enforcement is not contrary to the public policy 'or to the principles of the law' of the country in which it is sought to be relied on. Article 2, in turn, states three grounds for refusing recognition and enforcement: (a) annulment of the award in the country in which it was made; (b) due-process violations, 
such as insufficient notice of the proceedings or lack of proper representation; (c) the tribunal exceeded the scope of the submission.

However, the Geneva system had a major drawback. Article 4(2) provides that the party relying upon an award or claiming its enforcement must supply, inter alia, documentary evidence to prove that the award has become final-in the sense defined in Article 1(d) - in the country where it was made. Practically, this introduced a system of double exequatur, which, in effect, undermined the very purpose of this body of purportedly transnational rules. ${ }^{13}$

The Convention was adopted and signed by 18 states and eventually entered into force for 28 contracting states.

\subsection{Overall Assessment}

The principal merit of preparing and adopting the two Geneva instruments was that, afterwards, governments made a very significant effort to respond to businesses' needs to legitimise, in a harmonized manner, rules relating to transnational commercial dispute resolution. One might say that, after centuries of continued nationalization of the institutions administering and the rules governing commercial dispute resolution, it moved back to where it had belonged up until the mid-17 th century-at least in parts of the world and as regards important branches of trade. However, an important difference was, and continues to be, that it was now the national legal systems of sovereign states that provided a rule-based framework for such privately conducted judicial function.

There are no reliable data or reports on the application and the practical relevance of the two instruments as we have for the current regime of the 1958 New York Convention. Certain details, such as the positive and negative lists in Articles 1, 2 and 3 of the 1927 Convention, were remarkable. Yet much was left for the adoption of the New York Convention-as a truly global regime-and the 60 years that followed. ${ }^{14}$

13 Schlosser (n 8).

14 Herbert Kronke and others (eds), Recognition and Enforcement of Foreign Arbitral Awards: A Global Commentary on the New York Convention (1st edn, Kluwer 2010). 


\section{Conclusion}

After such a devastating conflict, the awareness that not only state-to-state relationships were in need of repair but that rebuilding functioning national economies and international commerce also required work on relevant private international law, or transnational commercial law, fortunately bore fruit. It was not governments, or the League of Nations, alone that were to be credited for the achievements briefly outlined in this paper but farsighted and intellectually strong personalities, such as Antonio Scialoja, Ernst Rabel, René David and a few others; they provided the leadership needed for transforming ideas into sound and coherent analysis and, eventually, legal texts that were adopted by states and became binding and relevant in commercial transactions. That has not changed since. And nothing, or very little, would have been achieved had there not been the support, indeed very substantial input, from the organizations of industry and commerce. That has not changed either. Finally, critics who might take issue with the, as they may feel, modest volume of work that actually came to fruition must be reminded of the exceedingly short period of time at the disposal of the individuals and institutions involved. For all practical purposes, work begun in the mid-1920s already came to a halt only ten years later. More specifically, work at UNIDROIT on the harmonization of the law of international sales, which to no small extent depended on its spiritus rector Ernst Rabel, remained an orphan six years after its effective commencement. Taking post-World War II experience with work cycles in the private-law formulating agencies into account, what was achieved-and ready to be built upon starting in the 1950s-was by no means disappointingly little. Finally, governments' resources available for participating in negotiations aimed at the modernization and international harmonisation of commercial law were limited then, as they are limited now. Taking into account, therefore, that the 1920s also witnessed major progress in relation to the law of carriage of goods by sea (1924 Brussels Convention 'Hague Rules') and by air (1929 Warsaw Convention), one cannot but admire the conscientiousness and the determination shown by many governments in such historically difficult circumstances. 